Document downloaded from:

http://hdl.handle.net/10251/85523

This paper must be cited as:

Joaquín M. Azagra-Caro (2011). Do public research organisations own most patents invented by their staff?. Science and Public Policy. 38(3):237-250. doi:10.3152/016502611X12849792159272.

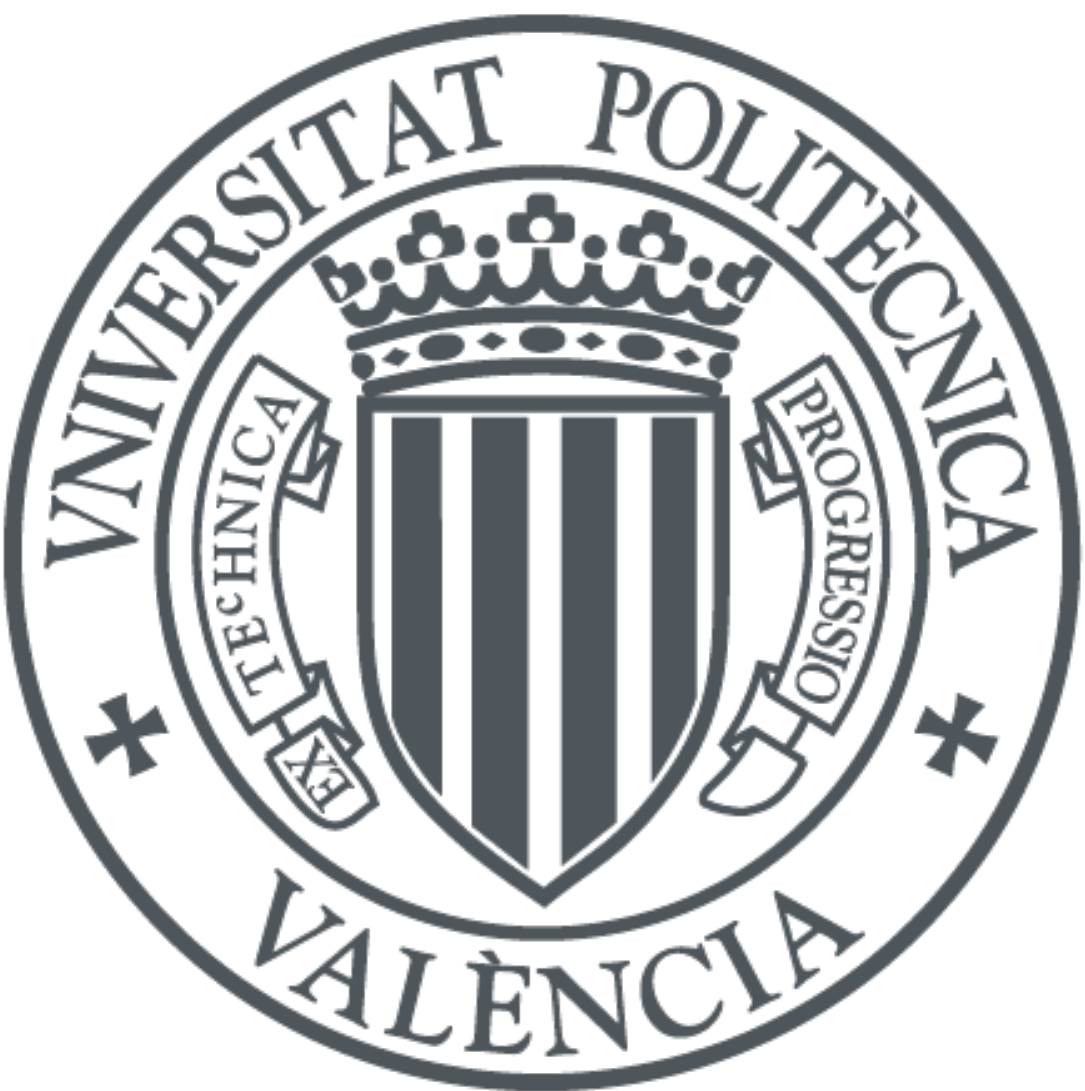

The final publication is available at

Copyright Oxford University Press (OUP)

Additional Information 


\title{
Do public research organisations own most patents invented by
}

\section{their staff?}

\section{Joaquí n M. Azagra-Caro*}

\begin{abstract}
Technology ownership and knowledge transfer aim at the dissemination of public research results usually in one direction - from the university or public research organisation (PRO) that produced the results. However, the complementarities between these types of instruments are not clear compared to the bidirectional channels of knowledge exchange. We analyse one PRO in Spain, a country that is peculiar in terms of infrequent changes to the legislations on science and patents and a predominance of PRO-owned over PRO-invented patents, similar to the situation in the USA but different from that in most EU member states. Against this background, knowledge transfer (measured through PRO-invented patents) increases faster than technology ownership (measured through PRO-owned patents). This situation may be damaging to knowledge exchange (measured through PRO co-owned patents).
\end{abstract}

Universities and public research organisations (PROs) - meaning all other public research organisations that are not universities - use various channels to play a more active role in disseminating research results to firms: they protect these results through patents which they can sell or license; they work for industry under contract to transfer what they know; they conduct joint research with companies. In this paper, we refer to these channels as technology ownership, knowledge transfer and knowledge exchange.

Technology ownership is rewarding for universities because it provides revenue from licensing. Filing patents is becoming more commonplace for universities even those that do not have the reputation of being very entrepreneurial (Mathieu et al, 2008). Policymakers are paying attention to university and PRO technology ownership, because monitoring it through number of university and PRO-owned patents enables an intuitive benchmarking of the 
technological research output of these institutions, whose output levels in Europe are apparently lower than in the US.

The second dissemination channel, knowledge transfer, can also be related to technological output in the form of patented inventions, because it involves external funding. Having access to the property rights of results is an incentive for other organisations, notably firms, to provide external funding to universities (Azagra-Caro et al, 2006a). Patent applications may include the names of these firms, but it is the university and PRO staff who will be listed as inventors. Hence, the contribution of universities and PROs to technology increases if we include the numbers of these so-called university and PRO-invented patents in university and PRO-owned patents. There is some evidence on Europe to suggest that doing so would reduce the perception that the EU is underperforming compared to US universities in terms of technological production (Dosi et al, 2006). A major policy recommendation would be to reduce the emulation of US patent legislation in Europe (Braunerhjelm, 2007; GöptekeHultén, 2008) and emphasise excellence in universities and technological strength in firms (Dosi et al, 2006). Continued support for patent ownership raises fears of greater disparities among universities because of a concentration of licensing income in a few privileged first movers, and increases the need for official statistics on university-invented patents (Geuna and Nesta, 2006).

This should provide some motivation for scholars to analyse both university/PRO-owned and university/PRO-invented patents. The production of systematic national evidence shows that in some European countries the number of university-invented patents is higher than the number of university-owned patents (Lissoni et al, 2008; 2009). So we would ask why do European universities not retain the intellectual property rights (IPR) on the inventions of their scientists? (Lissoni et al, 2008: 101). 
Although there is no aggregate evidence for all European countries, in those countries with a tradition of knowledge transfer there have been regulatory changes aimed at increasing technology ownership. On the contrary, some EU member states, such as Spain, have a tradition of university and PRO technology ownership, and not of knowledge transfer. Actually, Spain proportionally has fewer university-invented patents than other European countries (Crespi et al, 2006).

Our first research question therefore is: Is it true that university and PRO-invented patents predominate over university and PRO-owned patents in all EU countries? And the second and related research question is: What has been the evolution of both outputs under a stable legal framework that promotes technology ownership?

\section{Some theoretical considerations and further research questions}

We compare the three dissemination channels referred to in the introduction, based on their direction of transfer of results (unidirectional or bidirectional) and the degree of dissemination involved (actual or potential).

Technology ownership and knowledge transfer are both unidirectional in nature, but differ in that the actual transfer of knowledge from technology ownership depends on licensing. Knowledge exchange and knowledge transfer involve immediate dissemination, although the former is often in two directions (from the university or PRO to the firm and vice versa).

IPR ownership distribution is not the result of one or another model of knowledge dissemination, but sometimes the opposite. Consideration of university/PRO-owned and university/PRO-invented patents as additive measures of the contribution to technology overlooks the fact that they are related to different channels of research dissemination: technology ownership and knowledge transfer. It is important not to lose sight of this difference since EU R\&D policy tends to stress the overall importance of knowledge sharing 
and not only ownership of patents (EC, 2007). This would not matter if there were incentives for researchers to conduct project-based research leading to an institutionally owned patent while also engaging in contracts with firms and eventual industry patents.

Our third research question is: does technology ownership complement or substitute for knowledge transfer?

The research questions posed so far refer to the first and second dissemination channels. The third channel, knowledge exchange, is at least as important, because the probability of bidirectional flows of knowledge is higher. It can lead to patented inventions, normally coowned by the university/PRO and the partnering institution. Bach and Llerena (2007) show that regulatory changes to foster university patent ownership may paradoxically lead to less knowledge transfer to industry.

Our fourth research question is: what is the relationship of knowledge exchange with the other dissemination channels?

To answer these questions we identify PRO co-owned patents and invented patents. Their combination provides a measure of $\mathrm{R} \& \mathrm{D}$ cooperation and demonstrates the importance of cognitive proximity and personal relations (Balconi and Laboranti, 2006) and of top patenting, top publishing public researchers on firms' R\&D productivity (Baba et al, 2009).

In 2009, the topic of most interest in the EU policy context is to what extent is cross-border university and PRO-industry cooperation contributing to the realisation of the European Research Area (ERA) (EC, 2007). Or, is EU university and PRO cooperation oriented towards other EU institutions or towards other parts of the world? This is the fifth research question.

Note that the discussion so far has focused especially on universities. This is because universities have received more attention than other public producers of knowledge. The issue of technology ownership by PROs is also important, because these PROs are under the same 
sorts of funding pressures as universities (Laudel, 2006; Sanz-Menendez and Cruz-Castro, 2003). Furthermore, the promotion of technology ownership at PROs is subject to similar regulatory changes such as deciding between the researcher or the institution's privilege (Potì and Reale, 2005) and may encounter similar obstacles due to lack of individual rewards for scientists (Moutinho et al, 2007).

It is possible to claim that no parallel can be drawn between ownership patterns related to PRO-invented patents, and university-invented ones. This is because the contractual relationship between academic scientists and their universities may differ from the one between PROs and their scientists. Traditionally, academic scientists perform research by drawing on external funds, so ownership of a patent does not go to the university, but to the organisation that pays for the inventive effort, so it does not come as a surprise that many academic patents are owned by business companies. On the contrary, PRO scientists mostly perform research funded by the same PRO for which they work, which will naturally reclaim property over the results. However, not only internally-funded but also government-funded university research tends to produce university-owned patents (this was the main change introduced by the Bayh-Dole Act in 1980 in the US, see Ganz-Brown, 1999; Jaffe, 2000). And if we add university and government funding, the proportion over total funding is about the same for universities and PROs in the EU27 (Table 1: columns 2-3). There are also similarities between universities and PROs in the relative freedom enjoyed by both, to engage in a number of contractual relationships that do not involve their employer, which will not (as a consequence) have a say on IPR matters (an extreme form of this freedom is the German and Scandinavian professor's privilege). Actually, the proportion of business funding of PRO R\&D has grown faster than that of university R\&D in the EU27, which suggests that PROinvented patents could have grown faster than university-invented patents (Table 1: columns $4-5)$. 
Table 1. Government and higher education expenditure on $R \& D$ by source of funding in the

\section{EU27 and Spain}

\begin{tabular}{|c|c|c|c|c|c|c|c|c|}
\hline & & Share of & & & & Share of & & \\
\hline & Share of & government & & & Share of & government & & \\
\hline & government & + higher & & Share of & government & + higher & & Share of \\
\hline & + higher & education & Share of & business & + higher & education & Share of & business \\
\hline & education & funding of & business & funding of & education & funding of & business & funding of \\
\hline & funding of & higher & funding of & higher & funding of & higher & funding of & higher \\
\hline & government & education & government & education & government & education & government & education \\
\hline & R\&D & R\&D & R\&D & R\&D & R\&D & R\&D & R\&D & R\&D \\
\hline & expenditure & expenditure & expenditure & expenditure & expenditure & expenditure & expenditure & expenditure \\
\hline Year & in the EU27 & in the EU27 & in the EU27 & in the EU27 & in Spain & in Spain & in Spain & in Spain \\
\hline 1992 & $:$ & : & : & $:$ & $93 \%$ & $89 \%$ & $4 \%$ & $7 \%$ \\
\hline 1993 & $90 \%$ & $89 \%$ & $6 \%$ & $6 \%$ & $91 \%$ & $90 \%$ & $4 \%$ & $6 \%$ \\
\hline 1994 & $90 \%$ & $88 \%$ & $6 \%$ & $6 \%$ & $91 \%$ & $90 \%$ & $4 \%$ & $6 \%$ \\
\hline 1995 & $90 \%$ & $88 \%$ & $6 \%$ & $6 \%$ & $87 \%$ & $84 \%$ & $5 \%$ & $8 \%$ \\
\hline 1996 & $90 \%$ & $87 \%$ & $5 \%$ & $6 \%$ & $88 \%$ & $86 \%$ & $5 \%$ & $7 \%$ \\
\hline 1997 & $88 \%$ & $86 \%$ & $6 \%$ & $6 \%$ & $86 \%$ & $86 \%$ & $5 \%$ & $6 \%$ \\
\hline 1998 & $87 \%$ & $85 \%$ & $7 \%$ & $7 \%$ & $84 \%$ & $83 \%$ & $6 \%$ & $7 \%$ \\
\hline 1999 & $86 \%$ & $85 \%$ & $8 \%$ & $6 \%$ & $84 \%$ & $85 \%$ & $7 \%$ & $8 \%$ \\
\hline 2000 & $88 \%$ & $85 \%$ & $6 \%$ & $6 \%$ & $84 \%$ & $88 \%$ & $6 \%$ & $7 \%$ \\
\hline 2001 & $86 \%$ & $85 \%$ & $7 \%$ & $7 \%$ & $83 \%$ & $84 \%$ & $7 \%$ & $9 \%$ \\
\hline 2002 & $87 \%$ & $85 \%$ & $6 \%$ & $6 \%$ & $87 \%$ & $83 \%$ & $4 \%$ & $8 \%$ \\
\hline 2003 & $87 \%$ & $85 \%$ & $5 \%$ & $6 \%$ & $84 \%$ & $87 \%$ & $8 \%$ & $6 \%$ \\
\hline 2004 & $86 \%$ & $85 \%$ & $6 \%$ & $6 \%$ & $84 \%$ & $84 \%$ & $7 \%$ & $7 \%$ \\
\hline 2005 & $84 \%$ & $85 \%$ & $8 \%$ & $6 \%$ & $86 \%$ & $87 \%$ & $7 \%$ & $7 \%$ \\
\hline 2006 & $83 \%$ & $84 \%$ & $9 \%$ & $6 \%$ & $87 \%$ & $86 \%$ & $6 \%$ & $8 \%$ \\
\hline 2007 & $82 \%$ & $84 \%$ & $9 \%$ & $6 \%$ & $87 \%$ & $86 \%$ & $6 \%$ & $9 \%$ \\
\hline 2008 & $83 \%$ & $85 \%$ & $9 \%$ & $6 \%$ & $:$ & $:$ & $:$ & $:$ \\
\hline Growth rate & $-9 \%$ & $-5 \%$ & $53 \%$ & $8 \%$ & $-7 \%$ & $-4 \%$ & $50 \%$ & $23 \%$ \\
\hline
\end{tabular}

Source: Author's elaboration of Eurostat's Statistics on research and development ${ }^{1}$ 
These trends are also present in Spain, the research context for our empirical investigation (Table 1: columns 6-9). In the following sections, we discuss this context deeper, and the top patenting Spanish PRO, the Spanish National Research Council (CSIC). We describe the data and methodology, present the results and offer some conclusions.

\section{Research context ${ }^{2}$}

In the 1980s, a set of major regulatory and institutional changes in Spain established a stable framework for scientific and patenting activities.

The first of these was the 1983 University Reform Law, which allowed university researchers to receive income from contracts with firms, including contracts that led to patents and licensing. This was somewhat of a novelty; for instance, in France, these revenues always revert to the researcher's laboratory. For a researcher to gain personal income it is necessary to create a spin-off firm. In Spain, researchers could enhance their salaries with income from contract work, and this enhancement has increased over time (Vence Deza, 1995: 426).

The 1986 Law for the Promotion and General Coordination of Scientific and Technological Research or the Science Law, extended this privilege to PROs. More importantly, it introduced four annual R\&D plans to consolidate and better manage a sustained increase in funding for scientific activities, with the first beginning in 1988. It aligned the science system with the generally increased autonomy in the Spanish regions and Spain's entry to the EEC. It put emphasis on the need for universities and PROs to be in line with societal needs and particularly economic development. It marked a change from the lack of explicit regulation regarding IPRs at universities and PROs to clear entitlement for the retention of ownership of any research results. Institutions have autonomy to set the share of the royalty payments with inventors: in practice, usually split 60:40 in favour of the research institution. 
In 1986 the Patent Law was passed. It updated the situation regarding IPRs (the former law came into force in 1929) and provided for clearer application rules, scope of patentability, renewal fees, infringements, litigation, adaptation to European standards, etc. The Patent Law applies to every type of institution involved in patenting, including universities and PROs. However, universities are also exempt from Spanish Patent Office fees (Represa-Sanchez et $a l, 2005)$, on the basis that patents are a necessary good required for universities to fulfil their goals. In the immediate years following introduction of the patent law, the process of internationalisation of patents gained from subscription to the European Patent Agreement (1987) and the Patent Cooperation Treaty (1989), gave Spain protection under European Patent Office (EPO) and World Intellectual Property Organization (WIPO) applications, respectively -although these applications are subject to fee payment. Since this time, patenting has gained recognition in terms of promoting scientific researchers (Guasch, 2007).

Thus, Spain is a privileged environment for the establishment of technology ownership and knowledge transfer (perhaps more than knowledge exchange). The percentage of business funding of university and PRO R\&D, currently around 7\% of total university and PRO R\&D expenditure, and among the highest in the EU, is an illustration. Similarly universities and PROs show good levels of patent ownership $-8 \%$ and $2 \%$ of total Spanish patent applications respectively (OECD, 2007: 30-31). ${ }^{3}$

Since many studies on Europe and other parts of the world (e.g. Tang, 2008), draw parallels with the US Bayh-Dole Act we try to also make some comparison. However, the compartmentalisation established by the three Spanish Laws makes this problematic. What we can say is that by the 1980 s the regulatory framework in Spain was very similar to that in the US, although it was not directly inspired by the US model.

The 1980s also established the primacy of CSIC as a PRO in Spain. It was founded in 1939, and structured across several so-called 'boards', which made control straightforward during 
the Spanish dictatorship (1939-1975). In 1977, there was a major restructuring of CSIC: the boards were replaced by democratic mechanisms, and regulation of the links with the Ministry of Education and Science modernised the institution. A regulation introduced in 1984 governed the procedure for the creation and working of CSIC institutes and centres. CSIC currently works in eight scientific areas: Humanities \& Social Sciences, Biology \& Biomedicine, Natural Resources, Agriculture, Physics, Materials, Food, and Chemistry. There are more than 100 institutes and centres across the Spanish territory, and it is the main research actor in Spain. Its functions are similar to those of the German Max Planck Society, the French National Scientific Research Centre (CNRS) and, to a lesser extent, the Italian National Research Centre (CNR), however national idiosyncrasies introduce much heterogeneity, e.g. CNRS is deeply imbricated with universities and CNR is also a research funder. ${ }^{4}$ CSIC has fewer resources the above-mentioned PROs, measured in budget per researcher (Table 2). However, in terms of patent ownership, like CNRS and CNR, it is ahead of the national universities and PROs in Spain (Cesaroni and Piccaluga, 2005). It is actually the first Spanish organisation in WIPO and Spanish patent applications and holds $45 \%$ of all patents applied for by Spanish universities and PROs (de Miguel et al, 2007).

Table 2. Comparison between CSIC and some homologous European PROs

\begin{tabular}{lllll}
\hline & Max Planck & CNRS & CNR & CSIC \\
Research staff & $12607(2007)$ & $11600(2007)$ & $4200(2008)$ & $10953(2006)$ \\
Total annual budget in billion Euro & $1.43(2007)$ & $3.37(2009)$ & $1.00(2007)$ & $0.68(2007)$ \\
Estimated total annual budget in thousand & 113.4 & 290.5 & 238.1 & 62.1 \\
Euro per researcher & & & &
\end{tabular}

Source: Author's elaboration of ERAWATCH Research Inventory ${ }^{5}$ 
Although in the 1980s, there was not a strong tradition of university and PRO partnerships with industry, technology ownership was highly valued as a way to disseminate research results. The promotion of technology transfer offices (TTOs) in Spain from 1989 was pioneering in the European context (Proton, 2007), and put emphasis on training personnel in technology ownership issues (Represa-Sanchez et al, 2005). The TTO established by CSIC in 1985, became the pattern for their subsequent spread (García and Sanz Menéndez, 2002). The TTO plays a very prominent role in the strategy of CSIC, as reflected in the institutional memories, and delegations of the TTO have been created in different regions.

The framework for science, patents, technology transfer and CSIC has remained virtually unchanged since the late 1980s. It therefore makes it a suitable object to study medium to long-term stability in the EU, in relation to the dissemination of research results.

This stable framework is not matched by stability in the actors involved. Since 1986, there have been two changes in the political parties in power in government, several governments during the legislatures, and changes in the ministries in charge of science and technology (S\&T) policy. Traditionally, governance was mainly shared by the Ministry of Industry (MITYC) and the Ministry of Education and Science (MEC), which represent different interest groups, and sometimes provokes controversies. In 2000-2004, a Ministry for S\&T was established. It assumed many although not all of the responsibilities of MITYC and MEC e.g. the universities still came under MEC. A change of government in 2004 resulted in the abolition of the Ministry for S\&T and a return to the previous regime. However, following the elections in 2008, a Ministry of Science and Innovation (MICINN) was created and given responsibility for much public R\&D and innovation related activity (Azagra-Caro, 2009).

Since 1986, CSIC has had nine different presidents, with a new one elected every 2.5 years on average, despite this appointment being valid for up to 4 years. Only a few completed their full mandate, none of them was renewed, and in two cases, they remained in power for only 
one year. Presidents resigned following changes in political power but also within the same legislatures. These resignations were often associated with changes in the leadership of the CSIC TTO.

Hence, despite the overall favourable funding environment for $R \& D$, cooperation with industry, and technology ownership, the frequent changes in leadership meant that CSIC has had little continuation in the patterns of research dissemination, as we will see next.

\section{Data and methodology}

Retrieving patent data based on inventors' names is time consuming. Even restricting our search to CSIC, we were obliged to select among the eight scientific areas: Chemical Science and Technologies (Chemistry) was chosen. Among universities, Chemistry is generally the area with the highest share of academic inventors (Lissoni et al, 2008) and it is definitely the area with most patents for CSIC (García and Sanz-Menéndez, 2003; Azagra-Caro et al, 2007), where Chemistry owns some $40 \%$ of all CSIC-owned patents ${ }^{6}$. From a corporate point of view, Chemistry is the science-based sector where firms are more likely to cooperate with universities and PROs, which means if there is predominance of university/PRO-invented over university/PRO-owned patents, it will show up here. Since 1992, chemical products have been patentable in Spain; before that time only chemical processes were protected (Martínez, 2009).

The area of Chemistry in CSIC covered 14 institutes or centres in 2008, 10 of which are included in our sample (see details in Table 3$)^{7}$. 
Table 3. CSIC institutes and centres in the area of Chemistry in 2008

\begin{tabular}{|c|c|c|c|c|}
\hline Spanish name & $\begin{array}{l}\text { English translation (in italics } \\
\text { if not official) }\end{array}$ & Acronym & $\begin{array}{l}\text { Included in } \\
\text { the sample }\end{array}$ & Joint with \\
\hline Centro de Investigación y & Pascual Vila Research and & CID & No* & \\
\hline Desarrollo Pascual Vila & Development Centre & & & \\
\hline Centro de Investigaciones & Cartuja Island Scientific & CICIC & No* & \\
\hline Científicas Isla de la Cartuja & Research Centre & & & \\
\hline Centro de Química Orgánica & Lora Tamayo Organic & CENQUIOR & No* & \\
\hline Lora Tamayo & Chemistry Centre & & & \\
\hline Instituto de Carboquímica & Institute of Carbochemistry & ICB & Yes & \\
\hline Instituto de Catálisis y & Institute of Catalysis and & ICP & Yes & \\
\hline Petroleoquímica & Petrochemistry & & & \\
\hline Instituto de Ciencia de & Materials Science Institute of & ICMA & No** & \\
\hline Materiales de Aragón & Aragón & & & \\
\hline Instituto de Investigaciones & Institute of Chemical and & IIQAB & Yes & \\
\hline Químicas y Ambientales & Environmental Research Josep & & & \\
\hline Josep Pascual Vila & Pascual Vila & & & \\
\hline Instituto de Investigaciones & Institute of Chemical Research & IIQ & Yes & University of \\
\hline Químicas & & & & Seville \\
\hline Instituto de Productos & Institute of Natural Products & IPNA & Yes & \\
\hline Naturales y Agrobiología & and Agrobiology & & & \\
\hline Instituto de Química Física & Rocasolano Institute of & IQFR & Yes & \\
\hline Rocasolano & Physical Chemistry & & & \\
\hline Instituto de Química Medica & Institute of Medical Chemistry & IQM & Yes & \\
\hline Instituto de Química & Institute of General Organic & IQOG & Yes & \\
\hline Orgánica General & Chemistry & & & \\
\hline Instituto de Tecnología & Institute of Chemical & ITQ & Yes & Polytechnic \\
\hline Química & Technology & & & $\begin{array}{l}\text { University of } \\
\text { Valencia }\end{array}$ \\
\hline Instituto Nacional del Carbón & National Institute of Carbon & INCAR & Yes & \\
\hline
\end{tabular}


For each one of the institutes in our sample, we obtained a list of personnel using information from the web pages, augmented with direct requests where necessary. The staff were in a variety of different professional categories. In this study, we selected the most senior CSIC functionaries (the group referred to as A1 in the Spanish public system, Table 4). It is unlikely that other staff would be sole inventors of patents; thus, this method allows us to capture most CSIC patents in Chemistry. Other staff includes lower level functionaries (technicians, assistants, etc.), temporary staff and visiting staff.

Table 4. CSIC A1-Group scales in 2008 (included in the sample)

Spanish name

Profesor de investigación

Investigador científico

Científico titular

Titulado superior especializado

\section{Literal English translation}

Research professor

Scientific researcher

Titular scientist

Specialised high degree holder

Based on this information, we built a database of 323 CSIC researchers in 2008. Of course, the disadvantage of this is that it excludes researchers who were not active in 2008, but were active in patenting in previous years: thus, we may be underestimating the general level of patenting. However, this limitation applies to the aggregate number of patents retrieved. Breakdowns by patent type is not a problem, since this bias will affect all the series making comparisons still valid.

We introduced researcher names manually into our data using espacenet ${ }^{8}$. We chose three patenting routes based on the diversity of the results (Azagra-Caro et al, 2006b):

- $\quad$ the Spanish Patent Office (OEPM), or the LP database in espacenet 
- the EPO, or the Worlwide database in espacenet with patent identifiers starting 'EP'

- $\quad$ the WIPO, or the Worlwide database in espacenet with patent identifiers beginning 'WO'.

Aggregating these results has advantages (e.g. giving greater weight to potentially more valuable patents) and disadvantages (e.g. multiple counting of patent families). In this study we chose a pragmatic approach - a first analysis of the aggregate results followed by a robustness check based on each patent route (see next section).

Espacenet has an inventor field which made it possible to perform the search on individuals. Since Spaniards generally have two last names (and our sample was mostly made up Spaniards), the search strategy was varied. We started with the narrowest form of the researcher name, e.g. the first of the last names. For unusual last names, the search produced a few results which we checked manually. More often, results were so numerous we had to restrict the search by including the first name; this strategy generated a more reasonable number of retrievals for checking. We completed the exercise by searching on both last names to allow for the possibility of misspelled first names or cases where only initials were available. In the (fortunately) few cases of very common first names and last names, we included them all to restrict the search.

The possibility of confusing the names was small in our case because of the two last names -an advantage in studying Spain compared to some other countries. In (again) the few cases where we had doubts, we contacted the researchers themselves to verify whether they were the inventors. Manual checking suggests that no Type 2 error (false positive) is introduced with this choice, following Lissoni et al (2006).

Nevertheless, there was still a possibility of missing information in the case of systematic mistakes or inconsistencies in the inventor field. To complete the search, we used a database of CSIC-owned patents from the CSIC TTO, which was used in the study by Azagra-Caro et 
al (2007). This allowed us to confirm whether for a given researcher we had retrieved all CSIC-owned patents. If a patent appeared in the TTO database which we had not found in espacenet, in a second stage we introduced the title in espacenet. This usually identified the patent, and often a new form of the researcher's name. We then introduced this new name in the inventor field to allow for the possibility of retrieving other patents not owned by CSIC but with the same CSIC inventor name.

Our final sample was 1488 appearances (participations) of CSIC inventors in 888 patents excluding translations of granted European patents (kind code equal to T3). The information in these patents allowed us to classify participations according to the following fields:

- Type of ownership: based on the applicant name, we manually created a field with two categories of patents -'CSIC-owned' and 'CSIC-invented' (i.e. patents with CSIC inventors applied for by institution other than CSIC); and another field to distinguish CSIC-owned patents into 'CSIC wholly-owned patents' and 'CSIC coowned patents'. Figure 1 depicts this. ${ }^{9}$

- $\quad$ Application year: 1984 to 2008

- $\quad$ Route of patenting: OEPM, EPO, WIPO

- Institutional sector of applicant: business enterprise, government, higher education or other

- Nationality of applicant.

We provide some details on the construction of these fields where necessary in the following sections. ${ }^{10}$ 


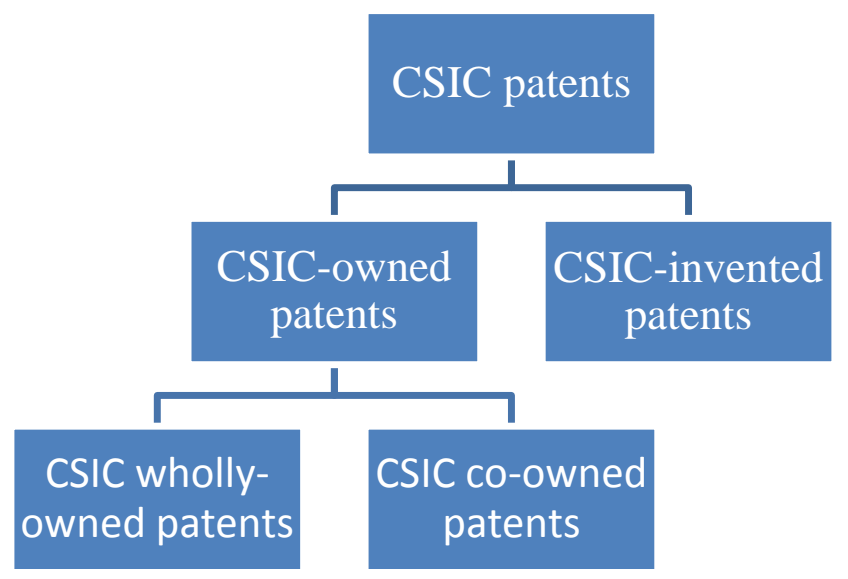

Figure 1. Participation in CSIC patents by type of ownership

\section{Results}

This section has five sub-sections. The first four present aggregated results of Spanish, EPO, and WIPO patent applications. The fifth sub-section (Robustness of the results: breakdown by patent route) validates the results for each one of them.

\section{Technology ownership and knowledge transfer}

The number of participations in CSIC-owned patents is always higher than in CSICinvented patents -three times higher on average during the period 1984-2008 (Figure 2). The time series are truncated and the decline in recent years is due to publication delays of up to 18 months after application, so what is important point is the comparison between the series the seeming decline may not be real.

In percentages, on average, CSIC-owned patents are 75\% and CSIC-invented patents are $25 \%$ of total patents. ${ }^{11}$ The proportion of university-invented patents in France, Italy and 
Sweden is $60 \%, 74 \%$ and $82 \%$, respectively, whereas it is $24 \%$ in the US (Lissoni et al, 2008). Thus Spain is more similar to the US than to many of its neighbours in this regard.

This goes against the idea that decision makers underestimate the contribution of public research to patented technology without counting university and PRO-invented patents (Dosi et al, 2006; Lissoni et al, 2008). Hence, there is still some context-dependency, which deserves further exploration. If the difference is between PROs and universities, more evidence on PROs is required. However, Azagra-Caro (2004) studies a Spanish university, the Polytechnic University of Valencia - one of the top universities in patent ownership in Spain, and finds equally higher numbers of university-owned than of university-invented patents as for Chemistry in CSIC. Citing a single case of a Spanish university which owns most of its scientists' patent is not enough. However, this is consistent with Crespi et al (2006), which show that Spain has few university-invented patents than other European countries. Thus, we think the difference is national. There are two possible explanations: the pioneering creation of TTOs in Spain and the unique possibility in Spain for researchers to receive personal income from licensing. ${ }^{12}$ 


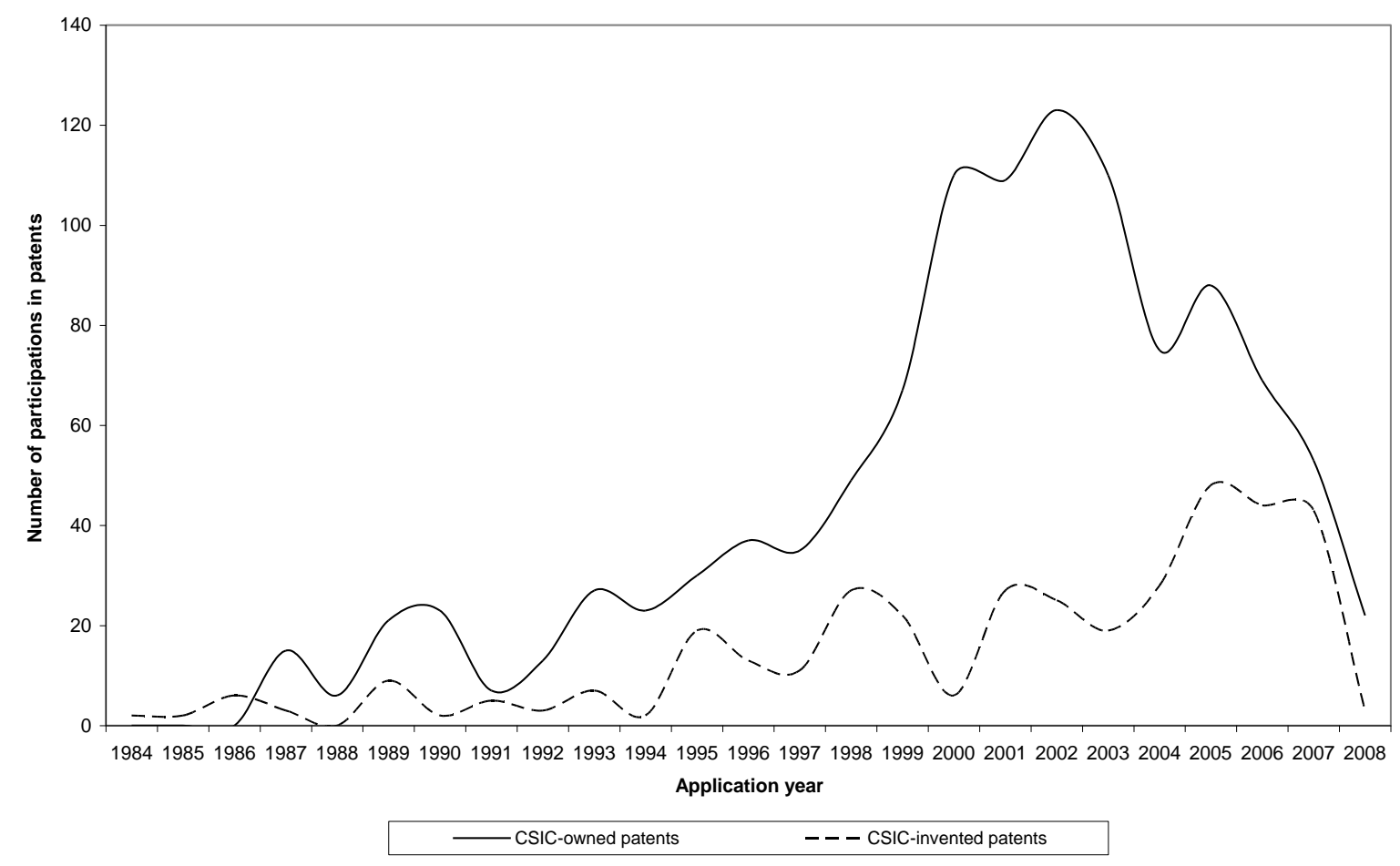

Figure 2. The prevalence of participation in CSIC-owned patents compared to CSIC-invented patents in Chemistry, 1984-2008

The growth in the number of participations in CSIC-owned patents is generally slower than in CSIC-invented patents. However, the trend is uneven over time (Figure 3) and depends on changes to CSIC's dissemination strategy, which in turn has depended on changes in the President of CSIC and the Director of the TTO. However, the increase in the number of participations in CSIC-invented patents tends to be in the second half of the 1990s and 2000s. This contradicts the belief that the impetus in the promotion of university and PRO-owned patents has favoured technology ownership at the expense of knowledge transfer. Also, some studies show a causality link between previous industry contacts and technology ownership at PROs (Moutinho et al, 2007) or complementarities with publication (Potì and Reale, 2005). Although we would not dismiss these findings, our results suggest a second causality link from technology ownership to industry contracts (leading to PRO-invented patents). 


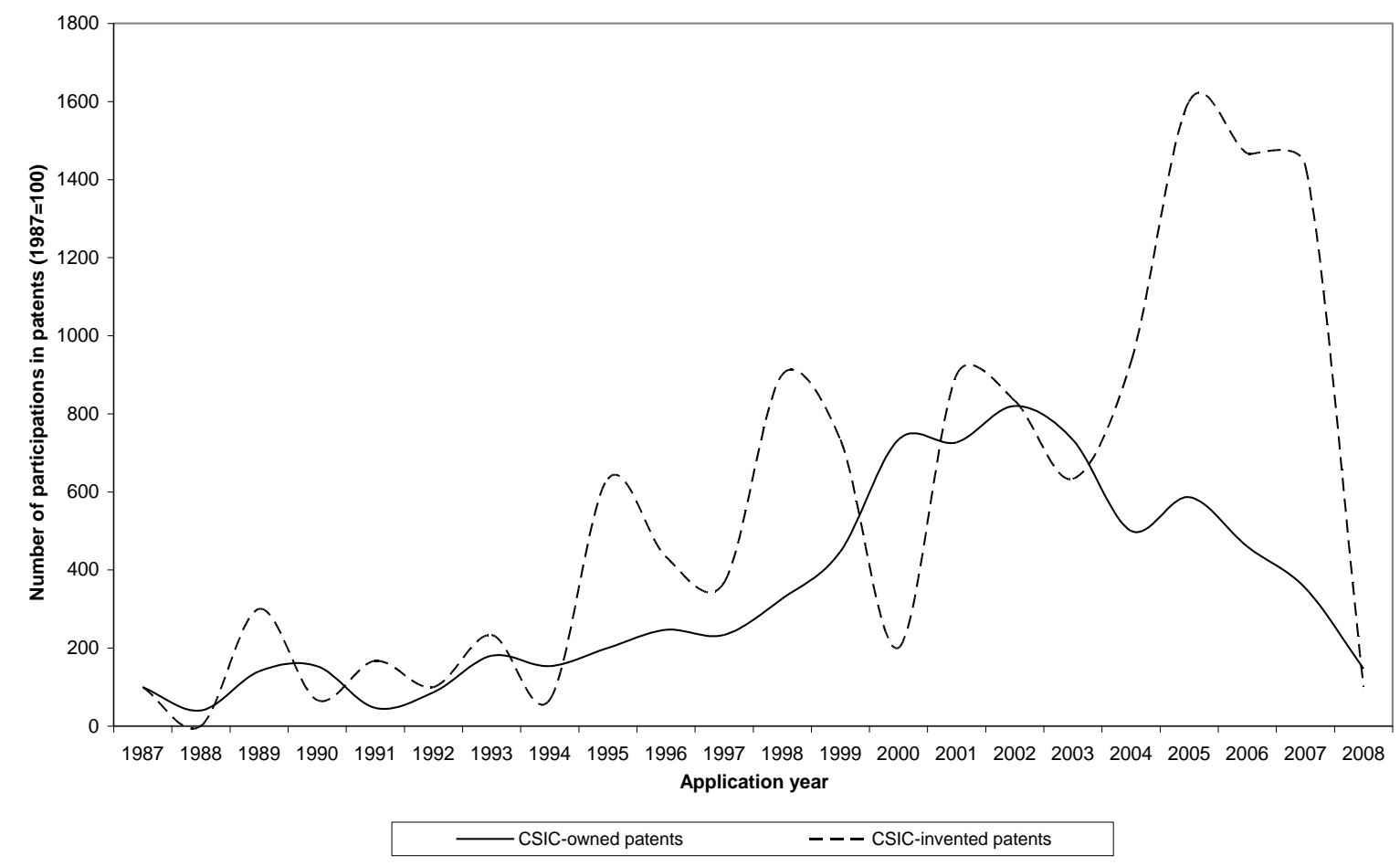

Figure 3. The (discontinuous) higher growth of participations in CSIC-invented patents over CSIC-owned patents in the area of Chemistry, 1987-2008

At the individual level, the patterns are similar. First, participating in CSIC-owned patents is more frequent -only $18 \%$ of inventors have more CSIC-invented than CSIC-owned patents. Second, the correlation coefficient between the number of participations in CSIC-owned patents and CSIC-invented patents is $82 \%$ for all researchers and $81 \%$ for inventors only. Thus, it is high in both cases. Again, this evidence is in favour of the existence of complementarity between both channels of research dissemination.

\section{Technology ownership and/or knowledge exchange}

Within CSIC-owned patents, it is possible to distinguish between wholly-owned and coowned patents. Here the period of observation shows an incipient trend reversal (Figure 4). Participations in CSIC wholly-owned patents predominated from 1987 to 2003, but the faster 
growth of participations in CSIC co-owned patents from the end of the 1990s reversed this situation in 2008. Although it is too soon to refer to a trend - especially in light of the truncation bias in the most recent years - the rising importance of co-patenting at CSIC is clear.

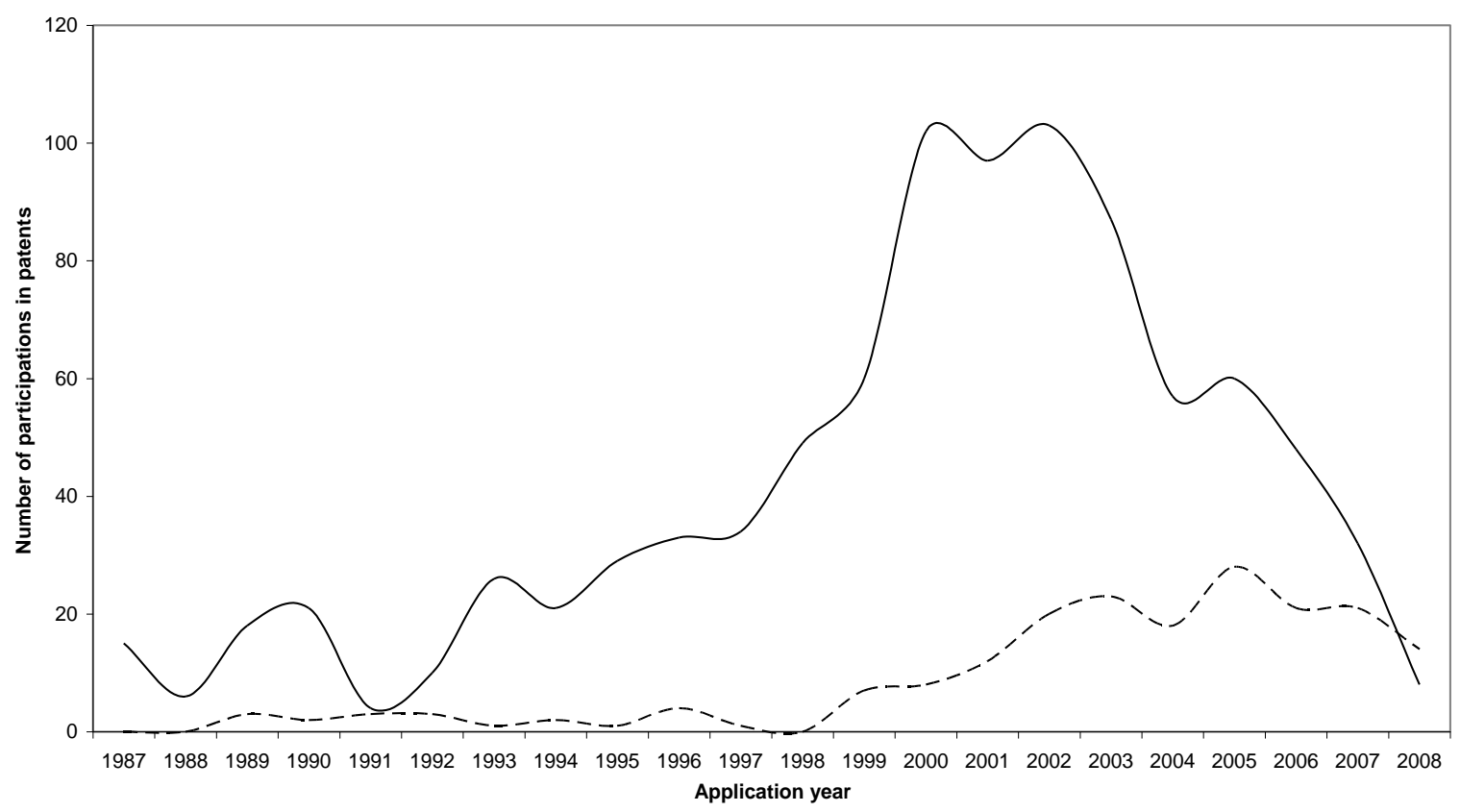

Figure 4. A change from a second to a first position for participation in CSIC co-owned patents in all CSIC-owned patents in the area of Chemistry, 1987-2008?

Compared to the complementary relation between participations in all CSIC-owned patents and CSIC-invented patents, participation in co-owned patents introduces some variety: at the individual level, the correlation between participations in CSIC wholly-owned patents and CSIC-invented patents is positive but small (13\% to $34 \%$, see Table 5). Therefore, copatenting can occur irrespective of involvement in other patenting practices. 
Table 5. The relation between participation in CSIC wholly-owned, co-owned and invented patents in the area of Chemistry, 1987-2008

\begin{tabular}{llllll}
\hline & All & Inventors - & Inventors - & Inventors - & Inventors - \\
$\begin{array}{lllll}\text { Correlation of number of } \\
\text { participations in CSIC co- }\end{array}$ & researchers & all patents & Spanish & EPO & WIPO \\
owned patents with... & & patents & patents & patents \\
$\begin{array}{l}\text { Number of participations in CSIC } \\
\text { wholly-owned patents }\end{array}$ & $27 \%$ & $22 \%$ & $17 \%$ & $17 \%$ & $16 \%$ \\
$\begin{array}{l}\text { Number of participations in CSIC- } \\
\text { invented patents }\end{array}$ & $34 \%$ & $28 \%$ & $20 \%$ & $14 \%$ & $24 \%$ \\
\hline
\end{tabular}

Knowledge exchange vs. knowledge transfer

Based on this low correlation between participation in CSIC co-owned patents and CSICinvented patents, it is interesting to investigate whether this is the result of the different networks associated with the underlying types of research activity (joint vs. contracted research) (see Figure 5).

In participations in CSIC co-owned patents, more than half of partners are universities, with firm involvement in less than a quarter of partnerships. In CSIC-invented patents, firms predominate - more than $80 \%$ of participations while the contribution of other types of institutions is small.

We can interpret this result in two ways. On the negative side, the scarce complementarities between co-owned and invented patents in PROs such as CSIC are associated with low involvement of firms in knowledge exchange, due to low institutional capacity to attract firms 
and/or to low absorptive capacity in firms. A different interpretation is that PROs like CSIC are organised so that they can focus on different ways of disseminating their research results.

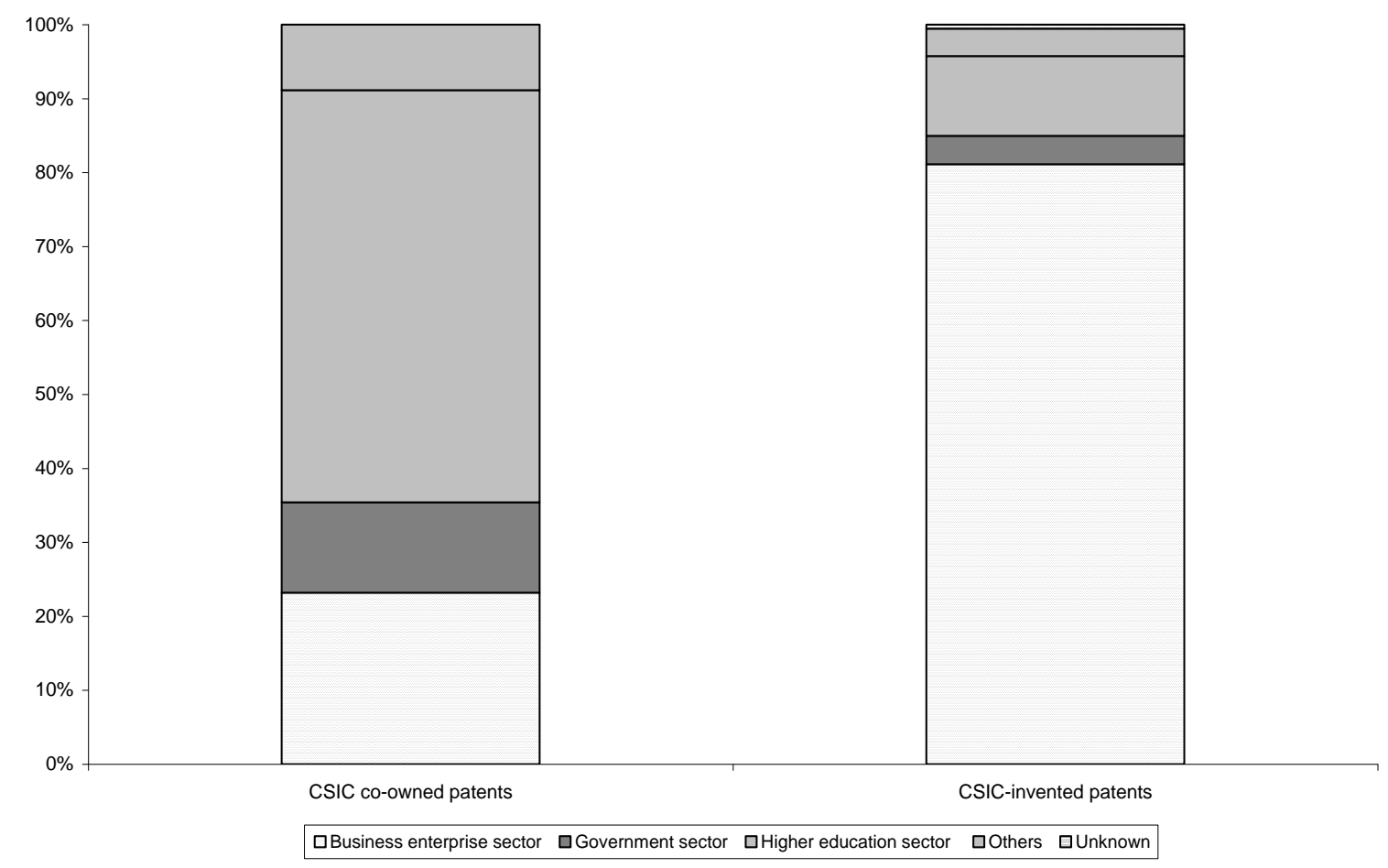

Figure 5. Different types of CSIC patents, different types of institutional partners in the area of Chemistry

We could focus on one institutional sector, i.e. firms and investigate whether firm presence in CSIC co-owned patents is the same as in CSIC-invented patents. Among the 82 firms that are either co-applicants in CSIC co-owned patents or applicants on CSIC-invented patents, only 2 appear in both groups. Hence, each type of patenting is related to different research dissemination strategies. 
In mid 2009, the European Commission was very concerned about how organisations conducting research should manage IPR beyond their national borders. The emergence of a ERA will mean the disappearance of the barriers to international cooperation, evidenced by co-applications for patents by partners from different countries.

We classified the partners of CSIC co-owned patents and the applicants of CSIC-invented patents according to their nationalities. Espacenet data usually attaches a code indicating the nationality of the applicant next to the applicant's name. In a small number of cases where the code was missing, we searched for a similar name and used the corresponding code. In the very few cases where this was not possible, we looked for the applicant name on the Internet in order to determine nationality. We achieved a $100 \%$ match. ${ }^{13}$

Spanish partners exclusively appear in around $70 \%$ of total participations in CSIC coowned patents plus co-invented patents; $30 \%$ have foreign partners. This would seem a quite a high percentage of cross-border patent ownership.

The growth in foreign partnerships has been faster than national partnerships. However, a preference for EU member states over other countries is not clear cut. In the $30 \%$ of foreign participations, partners are split 50:50 between EU and other countries and the evolution does not show obvious growth in one over the other (Figure 6). 


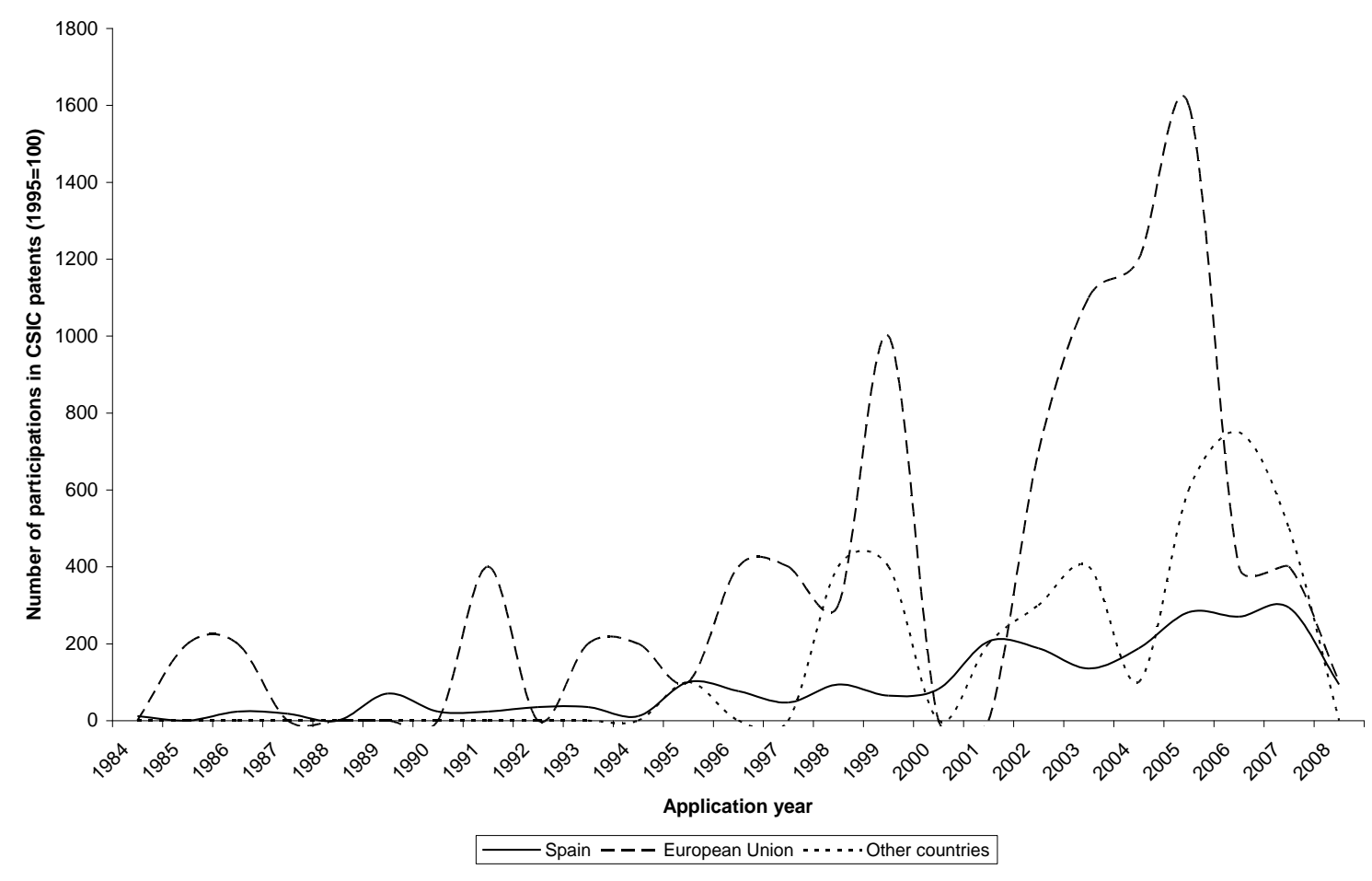

Figure 6. The similar growth of EU and other international partners of participations in CSIC co-owned and invented patents in the area of Chemistry, 1984-2008

Hence, although internationalisation of CSIC patents is an evident trend, Europeanisation is not. One explanation might be that total co-owned and invented patents, taken as a measure of collaboration, is increasing with cognitive proximity (Balconi and Laboranti, 2006), making geographical borders less important. For CSIC inventors who cooperate with partners abroad, it is irrelevant whether they are from the EU or not in terms of cognitive proximity.

Robustness of the results: breakdown by patent route

Notice that all tables and figures so far allow for multiple counting of patent families. As explained in the section "Data and methodology", this has the advantage of giving greater weight to potentially more valuable patents and the disadvantage of treating one invention as if was more than one. To correct for this, we replicate the analysis for each patent route. 
Actually, Spanish, EPO and WIPO patents are different in many respects. Spanish patent applications are rarely rejected; WIPO applications are not patents strictu senso but designations of protection through different national routes; EPO patenting is the most expensive of these three, and has the lowest granting rate. It further justifies a separate analysis of each route.

Table 6 provides a summary on the extent of potential multiple counting in the sample: most of the patents (less than a half) are national; PCT applications follow (a bit more than a third) and the rest (less than one quarter) are EPO patents. The series presented in previous sections could be at the extreme divided by 2.4 .

Table 6. Breakdown of CSIC patenting in the area of Chemistry, by patent route

\begin{tabular}{lll}
\hline Patent route & Number of participations & \% number of participations \\
OEPM & 627 & $42 \%$ \\
EPO & 334 & $22 \%$ \\
WIPO & 527 & $35 \%$ \\
All & 1.488 & $100 \%$ \\
\hline
\end{tabular}

Nevertheless, our key findings hold (Table 7). The predominance of participations in CSICowned patents holds even distinguishing by patent routes: it is higher for national patents, about the same for WIPO patents and lower for EPO patents. The correlation with participation in CSIC-invented patents is higher in the case of Spanish patents (85\%); it is lower for EPO and WIPO patents (a little over $70 \%$ in both cases). The faster growth of CSIC co-owned patents compared to CSIC wholly-owned patents is true for all three types. 
Table 7. Consistency of findings on CSIC patenting in the area of Chemistry, by patent route

\begin{tabular}{|c|c|c|c|c|}
\hline \# & $\begin{array}{l}\text { Finding for the aggregate number } \\
\text { of patents }\end{array}$ & $\begin{array}{l}\text { Confirmed for } \\
\text { Spanish patents? }\end{array}$ & $\begin{array}{l}\text { Confirmed for } \\
\text { EPO patents? }\end{array}$ & $\begin{array}{l}\text { Confirmed for } \\
\text { WIPO patents? }\end{array}$ \\
\hline$\# 1$ & $\begin{array}{l}\text { The prevalence of the participation } \\
\text { in CSIC-owned patents over CSIC- } \\
\text { invented patents }\end{array}$ & $\begin{array}{l}\text { Yes, more than for } \\
\text { the aggregate }\end{array}$ & $\begin{array}{l}\text { Yes, less than for } \\
\text { the aggregate }\end{array}$ & $\begin{array}{l}\text { Yes, as for the } \\
\text { aggregate }\end{array}$ \\
\hline$\# 2$ & $\begin{array}{l}\text { The (discontinuous) higher growth } \\
\text { of participations in CSIC-invented } \\
\text { patents over CSIC-owned patents }\end{array}$ & $\begin{array}{l}\text { Yes, more } \\
\text { continuous than for } \\
\text { the aggregate }\end{array}$ & $\begin{array}{l}\text { Yes, less continuous } \\
\text { than for the } \\
\text { aggregate }\end{array}$ & $\begin{array}{l}\text { Yes, slightly less } \\
\text { continuous than for } \\
\text { the aggregate }\end{array}$ \\
\hline \#3 & $\begin{array}{l}\text { The high relation between } \\
\text { participation in CSIC owned patents } \\
\text { and invented patents }\end{array}$ & $\begin{array}{l}\text { Yes, more than for } \\
\text { the aggregate }\end{array}$ & $\begin{array}{l}\text { Yes, less than for } \\
\text { the aggregate }\end{array}$ & $\begin{array}{l}\text { Yes, less than for } \\
\text { the aggregate }\end{array}$ \\
\hline \#4 & $\begin{array}{l}\text { The scarce relation between } \\
\text { participation in CSIC wholly-owned, } \\
\text { co-owned and invented patents * }\end{array}$ & $\begin{array}{l}\text { Yes, less than for } \\
\text { the aggregate }\end{array}$ & $\begin{array}{l}\text { Yes, less than for } \\
\text { the aggregate }\end{array}$ & $\begin{array}{l}\text { Yes, less than for } \\
\text { the aggregate }\end{array}$ \\
\hline \#5 & $\begin{array}{l}\text { The similar growth of EU and other } \\
\text { international partners of } \\
\text { participations in CSIC co-owned and } \\
\text { invented patents }\end{array}$ & $\begin{array}{l}\text { Too few } \\
\text { international } \\
\text { partnerships to be } \\
\text { confirmed }\end{array}$ & $\begin{array}{l}\text { Yes, as for the } \\
\text { aggregate }\end{array}$ & $\begin{array}{l}\text { Yes, as for the } \\
\text { aggregate }\end{array}$ \\
\hline
\end{tabular}

* See also Table 5.

Recall that the correlation between participation in CSIC wholly-owned, co-owned and invented patents (finding \#4) is lower for each separate set of patents than for the aggregate set. This means that if even the overall correlation between CSIC-owned and invented patents is not so strong. Finally, regarding research cooperation, we can consider that the Europeanisation (compared to cooperation with non-EU countries) does not emerge even if we examine EPO granted patents only. 


\section{Conclusions, limitations and suggested research lines}

The contributions of this paper are presented in the order of the five research questions.

(i) It is too soon to generalise that university/PRO-invented patents predominate over university/PRO-owned patent to all EU countries.

The preponderance of PRO-invented patents over similarly-owned patents is contextdependent. In cases such as Spain where ownership of an invention always belongs to the institution not the inventor, PRO-owned patents will be the rule, even in the absence of reinforcing regulatory changes, as indicated by our analysis of the field of Chemistry in CSIC. One limitation of our study is that we cannot generalise our results further (although Chemistry is representative of patenting involving university/PRO-industry interaction). We should point out assuming the reverse might also be premature.

(ii) Under a stable legal framework that promotes technology ownership, PRO-invented patents will grow faster than PRO-owned patents.

(iii) Both types of patenting can be complementary at the individual level, which could be interpreted in terms of complementarities between technology ownership and knowledge transfer, i.e. mainly unidirectional channels of dissemination of research results.

The evidence for Europe as well as ongoing research (Della Malva et al, 2008), suggests that regulatory changes supporting university and PRO patent ownership substitute for inventions by universities and PROs, replacing knowledge transfer with technology ownership. We find also that in the absence of such regulatory changes or specific directions, response to demands for better dissemination of research results can lead to a preference for PRO-invented patents, as in the Spanish case of CSIC. For example, researchers who previously generated inventions that were patented by their institutions are working under contract with especially industry and transferring their knowledge. Work-in-progress suggests 
that higher royalty shares from licensing income do not motivate researchers to produce more university-owned patents (Barrio-Castro and García-Quevedo, 2009), so they may look for other ways of augmenting their salaries. In other words, the disadvantages of technology ownership, namely delays in publication or changes to research agendas (Pénin, 2009) are leading university researchers to look for other ways to contribute to research dissemination.

(iv) One challenge is to make technology ownership and knowledge transfer complementary with the growing resource to knowledge exchange, a more bidirectional dissemination channel.

In our case study, PRO-invented patents are mostly owned by the business sector; whereas PRO-co-owned patents are essentially with universities. There are both negative and positive aspects. The negative include the fact that PROs like CSIC are less oriented to collaboration, especially with firms. One of the positive aspects is that institutions can nurture research groups interested in knowledge exchange even in the absence of an overall favourable environment. Linking this type of observation to the developing idea that author-inventors play a key role in bridging scientific and technological communities (Breschi and Catalini, 2008) would provide an interesting avenue for research: are the most frequent knowledge exchangers author-inventors? It is clear that if theoretical work to model the researcher's decision to patent is at an early stage (Göktepe, 2008), it would be useful to extend research to include the different technological contributions of the researcher.

(v) Another challenge is to assess whether the possible equality between shares in intra-EU and extra-EU PRO-industry cooperation responds to a policy target.

Our results have one methodological implication. We can retrieve data based on searching for PRO-owned patents, extract the inventors' names from these patents and then search for their PRO-invented patents. This would account for patterns in the contribution to technology 
of PROs such as CSIC. Thus, we could extend our study of the field of Chemistry to other scientific areas with marginal effort.

Our research suggests that the importance of personal financial reward from contractual arrangements is a key variable in international comparisons on the differences between PRO wholly-owned, co-owned and invented patents. To study the influence of regulatory changes in IPRs in Europe, our research highlights the utility of analysing the extent to which the US Bayh-Dole Act served as inspiration for the 1980s Spanish regulatory changes, an early European experiment in a US-like institutional setting.

It would be also possible to adopt the typology put forward by Sapsalis et al (2007) to identify the institutional sources of the different set of patents analysed in this paper, and rely on a similar approach to explain the dissemination of results generated by PROs. Through econometric regressions (with values of the dependent variables representing each a possible type of ownership) as a function of appropriate determinants, it would be possible to identify which are relevant, and how much.

* Joaquín M. Azagra-Caro started this paper at the European Commission's Joint Research Centre (JRC) - Institute of Prospective Technological Studies (IPTS). He finished it at CSIC - Consejo Superior de Investigaciones Científicas, Institute of Public Goods and Policies (IPP-CCHS). At the time of publishing, he is at INGENIO (CSIC-UPV), Ciudad Politécnica de Valencia, Edif. 8E $4^{\circ}$, Camino de Vera s/n, 46022 Valenica, Spain; Email: jazagra@ingenio.upv.es; Tel: +34 963877007 ext 78433; Fax: +34 963877991 .

The views expressed in this article are the author's and do not necessarily reflect those of the European Commission (EC). Neither the EC nor anyone acting on behalf of the EC is responsible for the use that might be made of the information.

The author acknowledges Ana Romero de Pablos for the ideas that inspired this paper and for her collaboration on previous studies that have considerably extended the author's knowledge of institutional issues. The author is also grateful for the thorough review and substantial comments made by Catalina Martínez and Luis Sanz-Menéndez; and for very useful conversations with Ignacio Fernández de Lucio and Luisa Henriques.

${ }^{1}$ Web page (last accessed: 25/3/2010):

http://epp.eurostat.ec.europa.eu/portal/page/portal/science_technology_innovation/data/database

${ }^{2}$ Although completely rewritten and with referenced additions, this section draws on Azagra-Caro et al (2007), Romero-de-Pablos and Azagra-Caro (2009) and Azagra-Caro and Romero-de-Pablos (2009).

${ }^{3}$ However, this is an optimistic point of view. General opinion is that even if technology transfer is growing and is widely accepted, further improvements are required, e.g. modifying the objectives of universities, professionalising TTO personnel, increasing university-PRO-industry research cooperation, etc. (Rodríguez Pomeda and Casani, 2007). 
${ }^{4}$ The focus of this paper is on PROs that are exclusively or mainly research performers. For PROs whose role as research funder is at least as important as a research performer, it would be intuitively expected a predominance of PRO-owned over PRO-invented patents, because they will most likely own the results of the research they fund, e.g. the NASA in US (Jaffe et al, 1998). However, the topic is understudied and even the proportion of patent rights waived from NASA to firms has been increasing (Jaffe et al, 1998).

${ }^{5}$ Web pages (last accessed: 18/8/2009):

http://cordis.europa.eu/erawatch/index.cfm?fuseaction=org.document\&UUID=7D87D148-BA450285-61720ABAE1E2A2BB\&hwd=max\%20planck

http://cordis.europa.eu/erawatch/index.cfm?fuseaction=org.document\&UUID=7D87CD70-ACB39F07-3581BF1E4C65F413\&hwd=cnrs

http://cordis.europa.eu/erawatch/index.cfm?fuseaction=org.document\&UUID=AF1263EE-A0F3FAA9-93E2E59018E4BCCD\&hwd=cnr

http://cordis.europa.eu/erawatch/index.cfm?fuseaction=org.document\&UUID=7D87C89E-E6D5956E-96956EB1E2E82B49\&hwd=csic

${ }^{6}$ Biotechnology is probably the most or at least second, important sector for academic patenting (Saragossi and van Pottelsberghe de la Potterie, 2003). Actually, the technological distribution of academic patents is changing over time and biotech appears to replace chemicals in the first positions (Lissoni et al, 2008).

${ }^{7} \mathrm{http}: / / \mathrm{www} . \mathrm{csic} . e s /$ centros_directorio.do?are $=8908$, last access: 01/07/2009.

${ }^{8}$ http://lp.espacenet.com/advancedSearch?locale=es LP

9 'CSIC wholly-owned patents' includes inventions patented by CSIC and institutions with which CSIC forms joint research centres because, by law, in the case of joint research centres, both mother institutions must appear as applicants, unless one of them explicitly declines. Hence, their coapplication does not indicate the same type of collaboration as in the case of co-patents with third party institutions. There are two joint research centres in our sample: the IIQ (CSIC-University of Seville) and the ITQ (CSIC-Polytechnic University of Valencia).

${ }^{10}$ Other breakdowns of the data are possible. Technology class has been of particular relevance in the literature. However, the focus of this paper on the scientific area of Chemistry makes this distinction less interesting, because the technology class of the patents in the sample is quite concentrated in Class C of the International Patent Classification (IPC): "Chemistry; Metallurgy" - almost 50\% of the patents belong to this category.

${ }^{11}$ Bach and Llerena (2008) find similar figures for French universities, but they dismiss the result, based on a survey of TTO, as an underestimation of inventions waived to other institutions.

${ }^{12}$ Anecdotal evidence suggests that, at the beginning of the period, there were only CSIC-invented patents. Only after the passage of the Science Law in 1986 did CSIC start to apply for patents, with the first ones appearing in 1987. However, absolute numbers are too low to talk about a trend reversal.

${ }^{13}$ Sometimes, there was more than one partner. If the nationalities of the partners were the same, we attributed this nationality to the participation. If different, we would have had to apply a fractional counting method. However, in the results we present here we aggregated countries into meaningful blocks, and there were no cases of applicants from different blocks, so there has no need to apply a fractional count.

\section{References}

Azagra Caro, J M 2004. La contribución de las universidades a la innovación: efectos del fomento de la interacción universidad-empresa y las patentes universitarias. Valencia: Universitat de València. 
Azagra-Caro, J M 2009. ERAWATCH Country Report 2008 - An Assessment of Research System and Policies: Spain. JRC Scientific and Technical Report 49546.

Azagra-Caro, J M and A Romero-de-Pablos 2009. Los determinantes institucionales de las patentes del CSIC: una aproximación histórica y una dialéctica con la economía. Revista Española de Documentación Científica, 32(2), 9-33.

Azagra-Caro, J M, N Carayol and P Llerena 2006a. Patent Production at a European Research University: Exploratory Evidence at the Laboratory Level. Journal of Technology Transfer, 31(3), $257-268$

Azagra-Caro, J M, L Plaza-Gómez and A Romero-de-Pablos 2007. The origin of public research organisation patents: an economic approach. Research Evaluation 16(4), 271-282

Azagra-Caro, J M, A Yegros-Yegros and F Archontakis 2006b. What do university patent routes indicate at regional level? Scientometrics, 66(1), 219-230.

Baba, Y, N Shichijo and S R Sedita 2009. How do collaborations with universities affect firms' innovative performance? The role of "Pasteur scientists" in the advanced materials field. Research Policy, 38: 756-764.

Bach, L and P Llerena 2007. Indicators of higher-education institutes and public-research organizations technology transfer activities: insights from France. Science and Public Policy, 34(10), 709-721.

Balconi, M and A Laboranti 2006. University-industry interactions in applied research: The case of microelectronics. Research Policy, 35, 1616-1630.

Barrio-Castro, T and J García-Quevedo 2009. The determinants of university patenting: do incentives matter? XII Encuentro de Economía Aplicada. Madrid, Spain, 4-6 June 2009.

Braunerhjelm, P 2007. Academic entrepreneurship: social norms, university culture and policies. Science and Public Policy, 34(9), 619-631.

Breschi, S and C Catalini 2008. Tracing the linkages between science and technology: an exploratory analysis of the research networks among scientists and inventors. Druid 25th Celebration Conference 2008. Copenhagen, Denmark, June 17-20 2008. 
Cesaroni, F and A Piccaluga 2005. Universities and Intellectual Property Rights in Southern European Countries. Technology Analysis \& Strategic Management, 17(4), 497-518.

Crespi, G A, A. Geuna and B. Verspagen 2006. University IPRs and Knowledge Transfer. Is the IPR ownership model more efficient? SPRU Working Papers, 154.

De Miguel, J L, D Represa, J Etxabe 2007. Patentes en la generación, protección y transferencia de tecnología: la experiencia del CSIC, mimeo.

Della Malva, A, F. Lissoni and P Llerena 2008. Institutional Change and Academic Patenting: French Universities and the Innovation Act of the 1999. BETA Working Paper, 2008-9.

Dosi, G, P Llerena and M S Labini 2006. Science-Technology-Industry Links and the 'European Paradox': Some Notes on the Dynamics of Scientific and Technological Research in Europe. In How Europe's Economies Learn: Coordinating competing models, eds. E H Lorenz and B - $\AA$ Lundvall. Oxford: Oxford University Press.

EC 2007. Commission Green Paper The European Research Area: New Perspectives, COM(2007) 161.

Ganz-Brown C 1999. Patent policies to fine tune commercialization of government-sponsored university research. Science and Public Policy, 26(6), 403-414.

García, C E and L Sanz Menéndez 2002. From research to patents within Spanish Public Research Organisations. Unidad de Políticas Comparadas Working Paper 02-26.

Geuna, A, and L J J Nesta 2006. University patenting and its effects on academic research: The emerging European evidence. Research Policy, 35, 790-807.

Göktepe, D 2008. A Theoretical Framework for Understanding University Inventors and Patenting. Jena Economic Research Papers, 2008-031.

Göpteke-Holtén, D 2009. Academic inventors and research groups: entrepreneurial cultures at universities. Science and Public Policy, 35(9), 657-667.

Guasch, L M 2007. Nuevas perspectivas en la evaluación de las patentes como parte del curriculum científico. Revista Española de Documentación Científica, 30(2), 218-240.

Jaffe A B 2000. The US patent system in transition: policy innovation and the innovation process. Research Policy, 29, 531-557. 
Jaffe A B, M S Fogarty and B A Banks 1998. Evidence from Patents and Patent Citations on the Impact of NASA and Other Federal Labs on Commercial Innovation. Journal of Industrial Economics, 46(2), 183-205.

Laudel, G 2006. The art of getting funded: how scientists adapt to their funding conditions. Science and Public Policy, 33(7), 489-504.

Lissoni F, B Sanditov and G Tarasconi 2006. The Keins Database on Academic Inventors: Methodology and Contents. CESPRI Working Paper 181.

Lissoni, F, P Llerena, M McKelvey and B Sanditov 2008. Academic patenting in Europe: new evidence from the KEINS database. Research Evaluation, 17(2), 87-102.

Lissoni, F, P Lotz, J Schovsbo and A Treccani 2009. Academic patenting and the professor's privilege: evidence on Denmark from the KEINS database. Science and Public Policy, 36(8), 569607.

Martínez, C. 2009. Patenting chemical inventions in Spain. Chemistry Today, 25(5), 6-8.

Mathieu, A, M Meyer and B van Pottelsberghe de la Potterie 2008. Turning science into business: a case study of a major European research university. Science and Public Policy, 35(9), 669-679.

Moutinho, P S F, M Fontes and M M Godinho 2007. Do individual factors matter? A survey of scientists' patenting in Portuguese public research organizations. Scientometrics, 70(2), 355-377.

OECD 2007. Compendium of Patent Statistics. Paris: Organisation for Economic Cooperation and Development.

Pénin, J 2009. On the consequences of university patenting: what can we learn by asking directly to academic inventors? BETA Working Paper, 2009-04.

Potì, B and E Reale 2005. The patenting regime in the Italian public research system. What motivates public inventors to patent. CERIS-CNR Working Paper, 10/2005.

Proton 2007. The ProTon Europe 2005 Annual Survey report, mimeo.

Represa-Sánchez, D, E Castro-Martínez and I Fernández-de-Lucio 2005. Encouraging protection of public research results in Spain. Jounal of Intellectual Property Rights, 10, 382-388.

Rodríguez Pomeda, J and F Casani Fernández de Navarrete 2007. La transferencia de tecnología en España. Diagnóstico y perspectivas. Economía Industrial, 366, 15-22. 
Romero-de-Pablos, A and J M Azagra-Caro 2009. Internationalisation of patents by Public Research Organisations from a historical and an economic perspective. Scientometrics, 79(1-2), 329-340.

Sanz-Menéndez, L and L Cruz-Castro 2003. Coping with environmental pressures: public research organisations responses to funding crises. Research Policy, 32, 1293-1308.

Sapsalis E. and B van Pottelsberghe de la Potterie 2007. The institutional sources of knowledge and the value of academic patents. Economics of Innovation and New Technology, 16(2), 139-157.

Saragossi, S and B van Pottelsberghe de la Potterie 2003. What patent data reveals about universities The case of Belgium. Journal of Technology Transfer, 28(1), 47-51.

Tang, M F 2008. Technology Transfers from University to Industry in the Chinese National Innovation system. Mimeo, doctoral thesis.

Vence Deza, X 1995. Economía de la innovación y del cambio tecnológico. Madrid: Siglo XXI. 